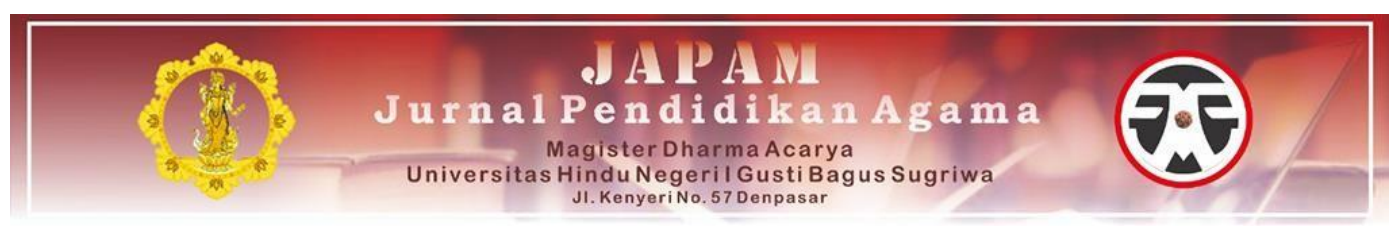

\title{
MEREKONSTRUKSI PENDIDIKAN KARAKTER MELALUI PERAN GURU DAN ORANG TUA TERHADAP KEBERHASILAN BELAJAR SISWA DISEKOLAH
}

\author{
Oleh: \\ I Kadek Arta Jaya \\ SMK N 5 Denpasar \\ e-mail: artadinajayaber217an@gmail.com
}

Diterima: 31 Mei 2021, Direvisi: 09 September 2021, Diterbitkan: 18 Oktober 2021

\begin{abstract}
Abstrak
Pendidikan merupakan media untuk mencerdaskan kehidupan bangsa dan membawa bangsa ini ke era pencerahan. Pendidikan bertujuan untuk membangun tatanan bangsa yang berdaulat dengan nilai-nilai kejujuran, kesopanan, kecerdasan, kepekaan dan kepedulian terhadap kehidupan berbangsa dan bernegara. Pendidikan kita sedang mengalami krisis karakter yang sangat menyedihkan. Kondisi yang sangat menyedihkan ini masih ditambah dengan kemerosotan akhlak seperti yang terjadi pada anak sekolah dan masyarakat. Penurunan moralitas anak-anak ini juga terjadi di SMK Negeri 5 Denpasar, dimana anak-anak sering terlambat ke sekolah, pada jam pelajaran masih ada anak-anak di luar kelas bermain di kantin, duduk-duduk mengobrol dengan teman, bertemu guru dan anak-anak lainnya. Anak jarang menyapa guru di sekolah. Atas dasar latar belakang tersebut, judul tulisan ini adalah merekonstruksi pendidikan karakter melalui peran guru dan orang tua. Dengan mengambil pembahasan tentang bagaimana kemitraan sekolah dengan orang tua, apakah pengaruh pendidikan karakter yang ditanamkan sejak dini dapat mengantarkan anak mencapai kesuksesan, dan merekonstruksi pendidikan karakter melalui konsep Tri Hita Karana. Penelitian ini menggunakan metode kualitatif dengan menggunakan studi kepustakaan. Studi literatur merupakan dokumen untuk melengkapi data yang diperoleh dari observasi dan wawancara. Dimana penelitian kepustakaan adalah suatu metode yang dilakukan dengan cara menggali, mengamati, mengkaji, dan mengidentifikasi pengetahuan yang ada dalam literatur (sumber bacaan, buku referensi atau hasil penelitian lainnya) untuk mendukung penelitian. Berdasarkan hasil analisis yang dilakukan, dapat disimpulkan bahwa untuk mencapai keberhasilan pendidikan perlu adanya kemitraan sekolah dengan keluarga. Karena dengan kemitraan antara sekolah dan keluarga, keberhasilan pendidikan akan tercapai, karena lingkungan keluarga adalah lingkungan pendidikan pertama, karena dalam keluarga inilah anak-anak pertama kali menerima pendidikan dan bimbingan; Pengaruh pendidikan karakter akan menentukan keberhasilan siswa di sekolah. Untuk mencapai keberhasilan pendidikan anak di sekolah perlu ditanamkan karakter anak seperti: rasa percaya diri; keramahan; dan kemampuan berkomunikasi agar kelak anak kita mampu membangun kepribadiannya sendiri sehingga tumbuh akhlak mulia; dan untuk membentuk karakter anak yang baik, konsep ajaran Tri Hita Karana sangat tepat untuk dikembangkan pada anak sejak usia dini di sekolah yang meliputi: karakter yang berhubungan dengan Tuhan Yang Maha Esa; karakter yang berhubungan dengan sesama manusia; dan karakter yang berhubungan dengan lingkungan.
\end{abstract}


Kata kunci: Rekonstruksi, Pendidikan, Peran guru, Orang tua, Kesuksesan pembelajaran

\begin{abstract}
Education is a medium to educate the nation's life and bring this nation to the era of enlightenment. Education aims to build a sovereign nation order with the values of honesty, politeness, intelligence, sensitivity and concern for the life of the nation and state. Our education is experiencing a very sad character crisis. This very sad condition is still compounded by the decline in morality as happened to school children and the community. The decline in the morality of these children also occurred at SMK Negeri 5 Denpasar, where children were often late for school, during class hours there were still children outside the classroom playing in the canteen, sitting around chatting with friends, meeting teachers and other children. Children rarely greet or say hello to teachers at school. On the basis of this background, the title of this paper is reconstructing character education through the role of teachers and parents. By taking a discussion about how the school's partnership with parents, whether the influence of character education that is instilled from an early age can lead children to achieve success, and reconstruct character education through the concept of Tri Hita Karana. This study uses a qualitative method by using a literature study. Literature study is a document to complete the data obtained from observations and interviews. Where library research is a method that is carried out by exploring, observing, examining, and identifying existing knowledge in the literature (reading sources, reference books or other research results) to support research. Based on the results of the analysis carried out, it can be concluded that to achieve the success of education, it is necessary to have a school partnership with the family. Because with the partnership between the school and the family, the success of education will be achieved, because the family environment is the first educational environment, because it is in this family that children first receive education and guidance; The influence of character education will determine the success of students in school. In order to achieve the success of children's education in schools, it is necessary to instill the character of children such as: selfconfidence; sociability; and the ability to communicate so that later our children will be able to build their own personality so that noble character will grow; and to form good children's characters, the concept of Tri Hita Karana's teachings is very appropriate to be developed in children from an early age in school which includes: characters related to the one and only God; character related to fellow human beings; and characters related to the environment.
\end{abstract}

Keywords: Reconstruct, Education, Teacher role, Parents, Learning success

\title{
I. PENDAHULUAN
}

Pendidikan adalah media mencerdaskan kehidupan bangsa dan membawa bangsa ini pada era pencerahan. Pendidikan bertujuan untuk membangun tatanann bangsa yang berdaulat dengan nilai-nilai kejujuran, kesopanan, kepintaran, kepekaan dan kepedulian terhadap kehidupan berbangsa dan bernegara. Pendidikan merupakan tonggak kuat untuk mengentaskan kemiskinan pengetahuan, menyelesaikan persoalan kebodohan dan menuntaskan segala permasalaha bangsa selama ini terjadi. Pendidikan dihadirkan 
untuk mengantarkan bangsa menjadi bangsa yang beradab dan berbudaya. Pendidikan dilahirkan untuk memperbaiki segala kebobrokan yang sudah mengumpul di segala sendi kehidupan di bangsa kita ini.

Zuchdi (2010:132) menyatakan bahwa kondisi masyarakat Indonesia pada saat ini menunjukkan bahwa telah terjadi suatu keguncangan yang cukup mengerikan dalam perkembangan peradaban bangsa kita. Nilai-nilai karakter dan nilai-nilai agama yang fundamental seperti penghargaan atas hak hidup seseorang ternyata sudah tidak lagi dijadikan landasan dalam bertindak oleh berbagai kelompok masyarakat di berbagai wilayah tanah air Indonesia. Rasa kasih sayang antara sesama mahkluk ciptaan Tuhan diganti dengan rasa kebencian yang dilancarkan oleh berbagai kelompok etnis, anggota partai politik, pemeluk agama, bahkan oleh komunitas yang secara historis terkenal memiliki jiwa gotong royong yang tinggi, yakni masyarakat pedesaan atau kampung. Kesadaran akan adanya harga diri dan empati dihancurkan oleh adanya ledakan emosi yang tidak terkendali akibat suhu politik yang memanas dan karena perbedaan idiologi partai politik serta perbedaan pilihan dalam politik.

Pendidikan kita mengalami krisis karakter yang sangat menyedihkan. Kondisi yang sangat menyedihkan tersebut masih ditambah dengan merosotnya moralitas sebagaimana terjadi pada anak-anak sekolahan dan masyarakat. Merosotnya moralitas anak-anak tersebut juga terjadi di SMK Negeri 5 Denpasar, dimana anak-anak sering terlambat masuk sekolah, pada saat jam pelajaran berlangsung masih ada anak-anak yang diluar kelas bermain dikantin, duduk-duduk ngobrol bersama temannya, bertemu gurupun anak-anak jarang bertegur sapa atau mengucapkan salam kepada guru disekolah. Tulisan ini berupaya untuk memberikan kontribusi pemahaman terhadap rekonstruksi pendidikan karakter melalui peran guru dan orang tua agar anak-anak kita dapat mencapai keberhasilan dalam belajarnya disekolah. Dalam tulisan ini penulis membahas persoalan tentang bagaimanakah kemitraan sekolah dengan orang tua, apakah pengaruh pendidikan karakter yang ditanamkan sejak dini dapat menghantarkan anak-anak untuk mencapai keberhasilannya, dan merekontruksi kembali pendidikan karakter melalui konsep Tri Hita Karana.

\section{METODE}

Tulisan ini menggunakan metode kualitatif dengan menggunakan kajian studi kepustakaan. Mulyana (2001:196) menyatakan bahwa studi kepustakaan adalah sebuah dokumen untuk melengkapi data-data yang didapatkan dari observasi dan wawancara. Sementara menurut Hasan (2002: 80) menjelaskan bahwa studi kepustakaan adalah suatu metode yang dilakukan dengan cara mendalami, mencermati, menelaah, dan mengidentifikasi pengetahuan yang ada dalam kepustakaan (sumber bacaan, buku-buku referensi atau hasil penelitian lain) untuk menunjang penelitian. Penulis melakukan kajian pustaka terhadap sumber-sumber ilmiah seperti buku, jurnal dan sumber yang relevan terkait rekonstruksi pendidikan karakter melalui peran guru dan orang tua untuk mencapai keberhasilan siswa.

\section{HASIL DAN PEMBAHASAN}

\subsection{Kemitraan Sekolah dan Keluarga}

Lingkungan keluarga merupakan lingkungan pendidikan yang pertama, karena dalam keluarga inilah anak pertama-tama mendapatkan didikan dan bimbingan. Juga 
dikatakan lingkungan yang utama, karena sebagian besar dari kehidupan anak adalah didalam keluarga, sehingga pendidikan yang paling banyak diterima oleh anak adalah dalam keluarga (Hasbullah, 2008: 38). Indrakusuma (1973: 109) menyatakan bahwa tugas utama dari keluarga bagi pendidikan anak adalah sebagai peletak dasar bagi pendidikan akhlak dan pandangan hidup keagamaan. Sifat dan tabiat anak sebagian besar diambil dari kedua orang tuanya dan dari anggota keluarga yang lain.

Berdasarkan pandangan ahli tersebut di atas, maka dapat jelaskan bahwa betapa besarnya tanggung jawab orang tua terhadap anak. Bagi seorang anak, keluarga merupakan persekutuan hidup pada lingkungan keluarga tempat dimana mereka menjadi diri pribadi atau diri sendiri. Keluarga merupakan wadah bagi anak dalam konteks proses belajarnya untuk mengembangkan dan membentuk diri dalam fungsi sosialnya. Disamping itu keluarga merupakan tempat belajar bagi anak dalam segala sikap untuk berbhakti kepada Tuhan sebagai perwujudan nilai hidup yang tertinggi.

Sementara sekolah adalah tempat kedua dalam pembentukan karakter anak-anak, disekolah anak-anak diajarkan disiplin dan tanggung jawab serta diberikan pengetahuan secara komprehendip oleh setiap guru yang mengajar dikelas. Oleh sebab itu, maka diperlukanlah kerjasama antara sekolah dengan keluarga. Kerjasama antara sekolah dan keluarga yang dapat dilakukan adalah dengan saling berkoordinasi terkait proses pendidikan anak-anak disekolah, baik dalam proses pembelajaran dikelas, tingkah laku anak-anak disekolah, perkembangan belajar anak-anak dikelas, baik mengenai perkembangan kognitif anak-anak maupun sikap dan karakter dengan selalu saling berkomunikasi antara sekolah dengan orang tua anak-anak disekolah. Dengan demikian kemitraan tersebut perlu ditingkatkan agar tidak terjadi kontradiksi atau ketidakselarasan antara nilai-nilai yang perlu di aplikasikan dan dapat dipegang teguh oleh anak-anak disekolah maupun yang harus mereka ikuti dilingkungan keluarga ataupun dimasyarakat.

Oleh karena itu kemitraan sekolah dan keluarga harus terus dijaga dan ditingkatkan, sebab apabila terjadi konflik nilai, anak-anak mungkin akan merasa bingung sehingga tidak memiliki pegangan nilai yang dapat dijadikan sebagai acuan dalam berperilaku. Hal inilah mengakibatkan akan terjadinya ketidak mampuan anakanak untuk mengontrol diri mereka dalam menghadapi pengaruh-pengaruh negative dari lingkungan disekitar mereka. Menurut Zuchdi (2010: 133-134) menyatakan bahwa kemitraan yang diperlukan tentu saja bukan yang bersifat formal berupa penandatanganan surat perjanjian atau yang serupa dengan itu, tetapi yang secara alami dan berkesinambungan dapat menyatukan langkah dalam mendidik putra-putri bangsa Indonesia. Sebagai seorang guru harus mampu menciptakan suasana yang kondusif bagi pendidikan karakter, baik disekolah maupun dirumah adalah merupakan salah satu bentuk kemitraan yang sangat perlu dikembangkan.

Dalam suasana kehidupan dirumah dan disekolah sangat memengaruhi akan perkembangan kepribadian siswa, karena hal itu merupakan wahana penyemaian nilainilai karakter yang akan dijadikan acuan oleh siswa didalam setiap tindakannya. Apabila siswa merasa tentram ketika berada disekolah, demikian juga halnya ketika si anak berada dilingkungan keluarga atau rumah, mereka diharapkan memiliki dorongan yang kuat untuk melaksanakan tugas sekolah dan tugas rumah dengan baik. Selain itu, anak-anak akan dengan sukarela menrima dan mengamalkan nilai-nilai karakter yang positif yang menjadi keyakinan mereka beserta keseluruhan anggota keluarga. Jika sebaliknya, anak-anak merasa tidak tenang dan gelisah dalam menghadapi pertentangan, atau tidak dipedulikan, maka perkembangan intelektual dan emosiaonal mereka akan 
terhambat. Sehingga dapat mengakibatkan nilai-nilai karakter mereka terabaikan dan nilai-nilai negatif akan mereka jadilan landasan dalam melaksanakan tindakan atau berperilaku menyimpang.

Menurut Schmuck dan Schmuck (1983: 30), menyatakan bahwa ada lima faktor yang dapat mendukung pengembangan suasana positif disekolah, dan juga dalam lingkungan keluarga yaitu partisipasi, kepemimpinan, persahabatan, norma, dan kekohesifan. Faktor pertama yang dapat mendukung pengembangan suasana positif disekolah dan lingkungan keluarga adalah adanya partisipasi. Jika semua pembicaraan dan informasi datang dari guru dan orang tua, sehingga anak-anak jarang berbagi (sharing) gagasan, maka anak-anak tidak akan mendapatkan kesempatan untuk mengembangkan keterampilan sosial atau keterampilan untuk mengadakan hubungan antar pribadi. Dimana anak-anak juga tidak mendapatkan kesempatan untuk berpartisipasi dalam pembuatan keputusan tentang kegiatan sekolah ataupun dirumah. Hal ini akan dapat mengakibatkan anak-anak tidak dapat melaksanakan tugas-tugas yang memerlukan perencanaa, kerjasama, dan salingketergantungan.

Untuk dapat mencapai keberhasilan dalam penerapan nilai-nilai karakter sebagai alat meningkatkan keberhasilan belajar siswa, maka diperlukan suasana kelas atau sekolah yang positif. Sebab suasana kelas atau suasana sekolah yang positif akan memungkinkan anak-anak dapat mengembangkan nilai-nilai fundamental yang sangat diperlukan dalam kehidupan sosial mereka disekolah, dirumah maupun dimasyarakat. Nilai-nilai tersebut antara lain adalah adanya kasih sayang antar sesama umat, adanya kemauan untuk mencapai yang terbaik dengan cara-cara yang sesuai dengan ajaran agama yang dianutnya. Sementara suasana kehidupan dalam keluarga seharusnya juga dikembangakan selaras dengan suasana sekolah. Komunikasi antar anggota keluarga hendaknya juga bersifat terbuka dan dilandasi dengan rasa kasih sayang yang tulus dan ikhlas. Dorongan untuk mencapai yang terbaik sesuai dengan kemampuan masingmasing anak senantiasa diberikan oleh orang tua, dan kesempatan bekerja secara tulus dan ikhlas perlu dibisaakan mulai dari keluarga. Sehingga dengan demikian anakanak akan memiliki acuan nilai karakter yang tidak kontradiktif ketika mereka berada diluar sekolah dan ketika mereka tinggal dirumah.

Sementara itu, nilai-nilai karakter positif yang seharusnya dikembangkan disekolah hendaknya juga diprogramkan untuk dikembangkan dikeluarga. Nilai-nilai karakter tersebut adalah merupakan hasil diskusi antara pihak sekolah dengan perwakilan orang tua siswa. Dan selanjutnya disosialisasikan kepada seluruh orang tua siswa. Caranya adalah dengan brosur-brosur, dan tidak harus dengan tatap muka dengan para orang tua siswa, dengan brosur-brosur tersebut dapat dibaca ulang oleh para orang tua siswa, ataupun apabila memungkinkan lebih baik dibacakan oleh anak kepada orang tuanya masing-masing dirumah. Sehingga dengan demikian guru-guru dan para orang tua yang tidak membiarkan anak-anak mengungangkapkan gagasan dan perasaan mereka, terlalu banyak mengontrol, akan dapat mengahambat daripada perkembangan emosional yang sangat diperlukan untuk bekerjasama dengan orang lain. Apabila guru dan orang tua membiarkan anak-anaknya berkembang secara wajar, maka hal tersebut dapat berdampak pada perilaku positif anak-anak pada proses belajar mereka disekolah. Dimana anak-anak akan secara bertahap dapat menirukan perilaku guru dan orang yang dianggap menjadi panutan dan suri tauladan mereka didalam bertingkah laku disekolah.

Menurut penulis para guru atau orang tua yang ingin mengembangkan suasana positif disekolah atau dilingkungan keluarga harus dapat memberikan dorongan kepada anak-anaknya untuk mengungkapkan gagasan dan perasaan mereka sendiri, membuat 
keputusan sendiri, dan berpartisifasi dalam menentukan tujuan belajar serta prosedur pencapainnya. Guru-guru dan orang tua juga harus dapat mengatur suasana kelas atau keluarga sedemikian rupa sehingga anak-anak dapat mendiskusikan masalahnya masi ng-masing secara bersama-sama.

Sementara itu faktor kedua yang dapat mendukung suasana positif sekolah adalah kepemimpinan. Dimana menurut Schmuck dan Schmuck (1983) bahwa kepemimpinan adalah suatu proses dapat memengaruhi orang lain. Menurut Schmuck dan Schmuck kemepimpinan dipandang sebagai perilaku untuk menolong suatu kelompok dalam mencapai suatu tujuan. Kepemimpinan yang menyenangkan terdiri dari adanya tindakan-tindakan yang dapat membantu dalam penentuan suatu tujuan, sehingga dapat meningkatkan kualitas interaksi individu, dan dapat menumbuhkan kekohesifan suatu kelompok sehingga dapat mengembangkan kompetensi setiap individu.

\subsection{Pengaruh Pendidikan Karakter Terhadap Keberhasilan Belajar}

Pendidikan tidak hanya mendidik para peserta didik untuk menjadi manusia seutuhnya, menjadikan mereka manusia cerdas, akan tetapi juga dapat membangun kepribadiannya agar manusia memiliki akhlak mulia. Oleh sebab itu, pendidikan karakter sangat penting untuk diterapkan disetiap sekolah hal ini dikarenakan pendidikan karakter yang baik memiliki keterkaitan yang sangat erat dengan keberhasilan anak didik dalam belajar disekolah. Menurut Joseph Zins, dkk sebagaimana dikutip oleh Muhaimin Azzet (2011: 41) menyatakan bahwa kecerdasan emosional yang didalamnya terkait erat dengan pendidikan karakter ternyata berpengaruh sangat kuat dengan keberhasilan belajar. Ada beberapa hal yang dapat menyebabkan adanya faktor resiko penyebab terjadinya kegagalan anak disekolah. Faktor-faktor risiko yang penulis sebutkan tersebut ternyata bukan karena terletak pada kecerdasan intelektual, melainkan karena faktor karakter anak itu sendiri.

\section{1) Rasa Percaya Diri}

Setiap pelaksanaan proses belajar mengajar disekolah, seharusnya anak didik dibangun agar memiliki rasa percaya diri yang baik pada dirinya sendiri. Rasa percaya diri tersebut dapat dikembangkan dengan memberikan bantuan kepada anak didik untuk dapat menemukan kompetensi dan kelebihan ataupun potensi yang ada dalam dirinya. Sebab, setiap manusia yang dilahirkan di alam semesta ini sudah mendapatkan anugrah dari Tuhan berupa Sabda, Bayu dan Idep atau diberikan kelebihan dari pada makhluk lainnya. Kelebihan tersebut berupa potensi atau kecerdasan yang sangat diperlukan untuk dikembangkan. Oleh karena itu, disinilah dibutuhkan kedekatan, kejelian, dan kesabaran dari seorang guru untuk dapat menemukan sekaligus dapat mengembangkan kelebihan atau potensi yang dimiliki oleh peserta didiknya.

Sebagai seorang guru sudah merupakan kewajiban untuk dapat memunculkan rasa percaya diri peserta didik dengan selalu memberikan kesempatan untuk mengerjakan sesuatu dengan penuh kepercayaan. Sebab, anak yang diberikan kepercayaan untuk melakukan sesuatu hal dengan sendirinya akan dapat menumbuhkan dan mengembangkan rasa percaya dirinya. Tidak banyak anak tidak memiliki rasa percaya diri karena memang tidak diberi kepercayaan dalam melakukan sesuatu hal. Sebab dalam banyak kasus, para orang tua tidak dapat membangun rasa percaya diri anaknya, malah para orang tua kebanyakan sekarang tidak mau membangun rasa percaya diri anaknya dan malahan justru mematikannya. Berdasarkan hasil pantauan dan pengalaman yang penulis alami sebagai seorang guru dan menjadi wali kelas disekolah, 
banyak para orang tua beralasan karena rasa cinta dan khawatir akan keberadaan anaknya yang berlebihan, para orang tua terlalu melindungi anaknya sehingga dilarang untuk melakukan segala sesuatu diluar jam belajar disekolah.. ironisnya lagi, ketika anak mendapatkan pekerjaan rumah dari sekolah pun ternyata para orang tua membantu anaknya, hal ini dilakukan dengan alasan untuk memberikan bantuan, dan malah orang tua yang mengerjakan tugas anaknya. Menurut penulis disinilah sesungguhnya peran orang tua dan guru disekolah hendaknya dapat memberikan suatu kepercayaan kepada anak didik disekolah maupun dirumah agar tumbuh rasa percaya dirinya didalam melakukan suatu pekerjaan yang diberikan oleh para gurunya disekolah.

Sebab, sebagai seorang guru dan orang tua sangat penting untuk dapat membangun rasa percaya diri anak didik. Sekadar contoh kecil, ada seorang anak yang memiliki kecerdasan intelektualnya bagus, kecerdasan emosionalnya juga bagus, akan tetapi apabila rasa percaya dirinya lemah, maka dia akan sulit bagi dirinya untuk memperoleh suatu keberhasilan ketika ia harus melakukan sebuah usaha. Didalam banyak kasus dilapangan, rasa percaya diri seorang anak bahkan diyakini sebagai salah satu kunci keberhasilan didalam kehidupannya. Artinya jelas sekali bahwasannya tanpa adanya suatu kepercayaan diri yang baik, potensi atau kelebihan yang dimiliki oleh anak didik bukannya bisa berkembang, akan tetapi justru akan semakin redup dan atau bahkan akan mati. Maka oleh sebab itu, rasa percaya diri dalam diri peserta didik disekolah maupun dirumah harus dapat dibangun dengan baik meskipun juga tidak boleh berlebihan. Sebab, jika berlebihan akan dapat membuat anak peserta didik kehilangan perhitungan atau bahkan akan menjadi sombong, angkuh dan egois.

\section{2) Kemampuan Bergaul}

Manusia merupakan makhluk yang bergelut secara intens dengan pendidikan. Itulah sebabnya manusia dijuluki sebagai animal educandum dan animal educandus secara sekaligus, yaitu sebagai makhluk yang dididik dan makhluk yang mendidik. Dengan kata lain, manusia adalah makhluk yang senantiasa terlibat dalam preses pendidikan, baik yang dilakukan terhadap orang lain maupun terhadap dirinya sendiri (Sukardjo dan Komarudin, 2009: 1). Selain itu manusia adalah mahkluk sosial yang tidak bisa hidup sendiri. Oleh sebab itu, manusia harus mampu bekerjasama dengan orang lain. Dalam proses pendidikan dibutuhkan kemampuan dalam menjalin kerjasama dengan orang lain, dimana anak didik juga harus dapat dibangun karakternya agar memiliki kemampuan bergaul. Kemampuan menjalin kerjasama tentu berbeda dengan kemampuan dalam bergaul. Dimana menjalin kerja sama adalah adanya hubungan dua belah pihak atau lebih dalam rangka melaksanakan suatu kesepakatan bersama, sedangkan kemampuan untuk bergaul adalah suatu kepandaian seseorang dalam menjalin hubungan sosial dengan siapa saja. Kemampuan dalam bergaul ini sangat terkait dengan keramahan, memahami orang lain, dan memperlakukan orang lain sebaik mungkin.

Menurut Azzet (2011: 45), bahwasannya orang yang pandai bergaul akan mempunyai banyak teman. Sudah tentu orang yang demikian akan merasakan banyak keuntungan. Bila ada masalah pun bisaanya tidak akan terlalu lama menjadi beban jiwa karena mempunyai banyak teman sehingga ada saja yang membantu, minimal dengan banyak bergaul, beban psikologis akan menjadi terkurangi atau bahkan akan menjadi hilang. Sehingga dengan demikian, orang yang pandai bergaul pun lebih sehat karena sebagian besar penyakit sesungguhnya disebabkan oleh beban psikologis yang tidak terurai. 
Sebagai seorang guru disekolah memiliki tanggung jawab dan kewajiban untuk membangun kepribadian si anak didik. Dengan demikian anak didik akan dapat mengembangkan kemampuannya dalam bergaul. Sebab, anak yang pandai dalam bergaul tentu akan menyenangkan dihadapan teman-temannya. Anak yang demikian bisaanya juga akan giat dan bersemangat dalam mengikuti kegiatan belajar mengajar disekolah. Menurut penulis inilah sebenarnya yang yang harus dimiliki dan diperlukan oleh seorang anak, yakni seorang anak harus memiliki kepribadian yang senang dan dapat menyenangkan orang lain. Jika hal ini ada ada anak didik maka, akan sangat berpengaruh terhadap semangatnya dalam belajar di sekolah. Hal ini sangat berbeda dengan anak yang tidak mudah bergaul, maka ia akan lebih banyak murung, menjauh dari teman-temannya, sehingga dapat prestasi belajarnya pun akan cendrung menurun serta tidak bagus. Oleh sebab itu, mau tidak mau, kemampuan dalam bergaul anak didik ini juga harus menjadi perhatian utama bagi seorang guru di sekolah pada saat melaksanakan proses belajar mengajar serta siapapun yang terlibat dalam proses belajar mengajar disekolah harus benar-benar mampu memperhatikan anak-anak didalam bergaul dengan teman-temannya.

\section{3) Kemampuan Berkomunikasi}

Pendidikan merupakan hal yang tidak bisa terpisahkan dari kehidupan manusia. Pendidikan adalah merupakan bagian dari kehidupan sosial yaitu adanya suatu proses yang timbul dari adanya hubungan manusia dengan masyarakat. Manusia senantiasa mempunyai naluri yang kuat untuk hidup bersama dengan sesamanya, manusia tidak akan hidup sendiri karena manusia disamping makhluk individu sekaligus juga makhluk sosial. Dengan demikian, manusia tidak akan bisa hidup menyendiri. Jika hidup secara menyendiri dilakukan dengan sengaja oleh manusia, maka akan sulit baginya untuk memperoleh kebahagiaan Karena telah menyalah kodrat dalam hidupnya sebagaimana diciptakan oleh Tuhan Yang Maha Esa.

Manusia adalah merupakan mahkluk social, maka ia harus mempunyai kemampuan dalam melakukan komunikasi sehingga ia bisa menjalin hubungan dengan dengan orang lain. Akan tetapi, alangkah menyedihkannya, ternyata tidak semua orang sebagai mahkluk social ini mempunyai kemampuan dalam berkomunikasi secara baik. Tidak jarang terjadi percekcokan antar individu, bahkan sering mengakibatkan terjadinya perkelahian antar anak-anak, antar warga hanya karena gara-gara tidak adanya kemampuan berkomunikasi secara baik dalam bergaul.

Sebagai manusia tidak bisa terlepas dari sebuah komunikasi dalam kehidupan bergaul. Apalagi, bagi anak didik dalam proses belajar mengajar, sudah tentu akan sulit untuk meraih suatu keberhasilan bila tidak bisa berkomunikasi dengan baik kepada sesame temannya disekolah dan dimasyarakat. Oleh karena itru, hendaknya seorang guru harus mempunyai keterampilan dalam membangun kemampuan anak didiknya untuk mampu berkomunikasi. Dalam hal ini, seorang pendidik atau guru harus memperbaiki kemampuannya dalam berkomunikasi dahulu. Sebab, bagaimana mungkin seorang guru dapat membangun kemampuan berkomunikasi anak didiknya jika ia sendiri belum mempunyai keterampilan dalam berkomunikasi.

Sebagai manusia ada satu hal yang mendasar harus dipahami dalam melatih kemampuan untuk berkomunikasi adalah bisa menjadi pendengar dengan baik. Karena kemampuan mendengar adalah merupakan kemampuan yang mendasar yang harus terlebih dahulu kita lakukan sebelum kita melakukan komunikasi dengan yang lain, maupun sebelum kita melatih kemampuan anak didik dalam menyampaikan sesuatu, 
baik itu dalam suara atau mulut, melalui Bahasa isyarat, maupun dengan menggunakan tulisan. Sebab, sepintar dan sepantai apapun seseorang didalam berkomunikasi, akan tetapi jika tidak mempunyai kemampuan untuk mendengan dengan baik lawan bicaranya, sesungguhnya mereka telah gagal dalam memahami orang lain.

Sehingga dengan demikianlah karakter sangat penting untuk dibangun pada diri anak didik agar mereka lebih mudah untuk meraih keberhasilan dalam proses belajar mengajar di sekolah maupun keberhasilan dalam menjalani kehidupan setelah mereka lulus dari sekolah. Goleman (1995 dan 1998), dalam penelitiannya menyatakan bahwa kecerdasan intelektual hanya berpengaruh dan memberikan kontribusi $20 \%$ terhadap kesuksesan hidup seseorang. Sementara $80 \%$ bergantung pada kecerdasan emosional dan kecerdasan spiritual. Bahkan keberhasilan didalam dunia kerja, kecerdasan intelektual hanya dapat memberikan kontribusi sebanyak 4\% saja. Berdasarkan pendapat dari Goleman tersebut, maka dapat dikatakan bahwa karakter sangat penting untuk dibangun pada anak-anak atau peserta didik, karena dengan memiliki karakter yang baik maka anak tersebut akan mampu bersaing dan mampu berkomunikasi dengan baik.

Sementara penulis berkesimpulan bahwasannya kecerdasan intelektual yang kini dianggap sebagai penentu kecerdasan di Indonesia, ternyata tidak mempunyai peran yang sangat signifikan dalam menentukan kesuksesan hidup seseorang. Justru yang lebih besar berperan menurut pandangan penulis adalah kecerdasan emosional dan kecerdasan spiritual. Hal ini dipicu oleh hati nurani setiap manusia yang tercipta oleh Tuhan, dimana seseorang yang memiliki kecerdasan emosional dan spiritual yang baik akan memiliki banyak teman, cerdas dalam berkomunikasi, mudah beradaptasi didalam lingkungan pergaulan sosial, sehingga kehidupannya bisa bermanfaat tidak hanya untuk dirinya sendiri akan tetapi untuk orang lain. Di era modern dan serba canggih seperti sekarang ini, jika kita melihat generasi kita sekarang yang sudah mengalami degradasi karakter, maka kemampuan seperti inilah yang sangat dibutuhkan oleh anak kita agar mereka dapat meraih keberhasilan dalam belajar dan kelak lebih mudah dalam menghadapi tantangan kehidupannya.

Jika kita mau melihat kenyataan dalam dunia pendidikan kita sungguh sangat menyedihkan. Hal ini dikarenakan oleh menurunnya nilai-nilai karakter bangsa. Oleh karena itu, sebagai seorang pendidik sudah harus bertanggung jawab dan dengan penuh ketulus ikhlasan untuk membangun karakter anak-anak disekolah dengan pembiasaan. Sebab, anak-anak yang tidak terbanguin karakternya dengan baik sebagaimana sudah dijelaskan di atas, harus segera mendapatkan bimbingan dan konsleng dengan baik dan tepat. Hal ini adalah merupakan tanggung jawab pendidik, lembaga pendidikan. Apabila tidak mendapat penanganan dengan baik, maka akan terbawa sampai usia dewasa. Oleh sebab itu, selagi usia masih anak-anak, pembangunan karakter dalam diri peserta didik atau anak-anak jangan sampai terlewatkan untuk dibangun dan dibenahi. Berdasarkan penjelasan di atas yang sudah disampaikan dengan jelas bahwasannya membangun pendidikan karakter harus secara sistematis dan tersusun dengan sistematis berdampak positif terhadap pencapaian akademis dan non akademis.

\subsection{Mengembangkan Pendidikan Karakter Berdasarkan Konsep Tri Hita Karana}

Lembaga pendidikan memiliki tugas mempersiapkan terbentuknya individuindividu yang cerdas dan berakhlak mulia. Terbentuknya kedua kriteria ini memungkinkan terwujudnya kehidupan sosial yang ideal bagi anak-anak, dan akan 
dapat mewarnai semangat untuk mengembangkan potensi diri dan memanfaatkannya untuk mencapai kebahagiaan lahir dan batin serta keselamatan dunia akhirat (Zuchdi, 2010:141). Untuk mencapai hal tersebut maka diperlukan adanya sistem sekolah yang kondusif dan tatanan tenaga pengajar dan karyawan yang produktif, terciptalah suatu kondisi yang kondusif pula dalam proses belajar peserta didik. Proses belajar merupakan jalan yang harus ditempuh oleh seorang pelajar untuk mengerti suatu hal yang sebelumnya tidak diketahui (Rooijakkers, 1993: 14). Dari pandangan ahli tersebut, disinilah sesungguhnya pengtingnya mengubah orientasi pendidikan di indonesia yang sebelumnya sangat menekankan pentingnya kecerdassan intelektual menjadi seimbang atau memerhatikan pula dengan porsi yang sama terhadap kecerdasan emosional dan kecerdassan spiritual. Pendidikan yang berbasis kecerdasan intelektual dan menghasilkan lulusan yang hanya memiliki prestasi dalam akademis diubah dengan memerhatikan pendidikan yang berbasis pada pembentukan karakter anak didik sehingga mampu bersaing, berertika, dan bermoral dalam menjalin hubungan sosial di masyarakat. Dengan pengembangkan pendidikan karakter pada anak didik akan dapat menumbuhkan nilai-nilai yang terkait dengan keimanan dan ketakwaannya kepada Tuhan Yang Maha Esa, sesama manusia, dan lingkungan masyarakat.

\section{1) Karakter Terkait dengan Tuhan Yang Maha Esa (Parhyangan)}

Nilai karakter yang terkait dengan Tuhan Yang Maha Esa adalah nilai religius. Nilai karakyer yang semestinya dikembangkan pada diri anak didik adalah terbangunnya suatu pikiran, perkataan, dan perbuatan/tindakan anak didik yang diupayakan senantiasa berdasarkan pada nilai-nilai Pancasila terutama Ketuhanan Yang Maha Esa dan disesuaikan dengan agama yang dianutnya. Dimana agama yang dianut oleh peserta didik benar-benar mampu dipahami dan dapat diamalkan dalam kehidupan bergaul disekolahnya sehari-hari.

Jika seorang peserta didik memiliki karakter yang baik terkait dengan Tuhan Yang maha Esa, maka seluruh kehidupannya akan menjadi baik. Akan tetapi, dijaman modern serba canggih ini karakter semacam ini tidak terbangun dalam diri peserta didik yang beragama. Hal tersebut bisa terjadi karena kurangnya kesadaran dalam keberagamaannya. Yang lebih menyedihkan lagi adalah ada peserta didik atau seseorang yang beragama hanya sebatas pengakuan saja beragama, namun dalam kehidupan sehari-hari ia sama sekali tidak mencerminkan orang yang benar-benar memahami ajaran agama, hal tersebut terlihat dari bersikap, cara pandang, serta berperilaku yang sesuai dengan ajaran agama yang dianut dan diyakininya.

Maka dari itu, penulis menyatakan bahwasannya dizaman modern serba canggih ini, peserta didik harus dikembangkan karakternya agar benar-benar memiliki keyakinan, bersikap, berkata-kata, dan berperilaku sesuai dengan nilai-nilai Pancasila terutama Sila Ketuhanan Yang Maha Esa. Untuk melaksanakan hal itu, sudah ditentu membutuhkan seorang pendidik atau guru-guru yang bisa menjadi contoh dan mampu memberikan contoh serta menjadi tauladan disekolah. Dalam hal ini bukan guru (orang tua) yang mengajarkan kepada anak didik agar taat dan patuh serta menjalankan ajaran Tuhan Yang Maha esa, sementara guru atau orang tua itu sendiri tidak taat dan patuh, sehingga yang menjadi tauladan dan contoh itu sendiri sebagai seorang contoh figur dan teladan tidak bisa menjadi contoh bagi anak didik. 


\section{2) Karakter Terkait dengan Sesama Manusia (Pawongan)}

Sekolah menjadi lembaga pendidikan sebagai media berbenah diri dan membentuk nalar berpikir yang kuat dengan ilmu pengetahuan dan teknologi serta untuk membentuk Karakter peserta didik dengan nilai-nilai luhur. Lembaga pendidikan atau sekolah juga mempunyai tanggung jawab yang besar dalam membangun karakter anak didiknya yang terkait dengan kemanusiaan.

Karakter yang terkait dengan sesama manusia ini sangat penting untuk dikembangkan karena manusia tidak bisa hidup tanpa adanya bantuan orang lain atau melibatkan orang lain dalam setiap tindakan dalam kehidupannya. Jika ada seseorang yang mengatakan dirinya bisa hidup dengan baik atau sukses tanpa memerlukan bantuan atau melibatkan orang lain, hal tersebut sungguh hanyalah suatu kesombongan yang justru akan membuatnya tersingkirkan dri kehangatan dan kebaikan hidup bersama orang lain atau sesama manusia.

Untuk membangun karakter yang terkait dengan sesama mansia adalah adanya kesadaran atau terbangunnya suatu kesadaran akan adanya hak dan kewajiban diri sendiri dan orang lain. Karakter ini sangat penting untuk dimiliki oleh anak didik, sebab tiada sedikit orang hanya menuntut haknya saja dari orang lain, akan tetapi dia sama sekali tidak pernh berpikir untuk memenuhi kewajibannya. Dalam hal ini penulis menyatakan bahwasannya karakter tersebut sangat perlu dikembangkan oleh sekolah atau lembaga pendidikan agar anak didik mengetahui dan mengerti serta dapat melaksanakan apa yang menjadi hak dan kewajiban diri sendiri dan orang lain serta dapat melaksanakan tugas atau kewajibannya sendiri.

Menurut penulis berkaitan dengan pemahaman hak dan kewajiban diri sendiri dan orang lain, ada karakter yang penting yang juga sangat perlu dikembangkan disekolah atau lembaga pendidikan pada diri anak didik yakni karakter kemampuan untuk memahami dan bersikap bahwa hak dan kewajiban dirinya sama dengan orang lain. Sebab dalam kehidupan bermasyarakat dan beragama tidak bisa hidup sendiri, karena kehidupan kita dengan orang lain saling terkait dan tidak bisa dilepaskan. Karakter untuk saling menghargai dan saling membantu atau disebut juga dengan karakter demokratis ini sangat penting untuk dikembangkan pada diri anak didik kita disekolah. Dalam karakter ini, seorang gutu harus mampu mengembangkan karakter tersebut pada anak didik terutama karakter sikap saling memahami, menghormati, toleransi antara satu dengan yang lainnya sesama manusia ataupun sama anak didik disekolah, terutama yang menyangkut dengan hak dan kewajiban. Jika karakter ini tidak ada pada diri anak didik disekolah, maka akan memunculkan pola kehidupan anak didik yang saling memaksa, tidak menghormati hak dan kewajiban orang lain, dan menomorsatukan kepentingan dirinya sendiri. Jika hal ini terjadi, maka sungguh tidak nyamannya kehidupan ini. Maka dari itu sekolah dan lembaga pendidikan lainnya harus membangun karakter demokratis atau karakter yang terkait dengan sesama manusia pada diri setiap anak didik kita disekolah.

Selain karakter tersebut di atas, bagi penulis karakter yang terkait dengan sesama manusia yang selanjutnya harus dibangun adalah adanya kemampuan seseorang untuk berkata maupun berperilaku santun dengan sesamanya dimasyarakat. Anak didik yang mampu bersikap sopan santun adalah anak didik yang halus dan baik budi pekerti, bahasa, maupun tingkah lakunya kepada guru, teman sejawat, orang tua dan pada orang lain. Sehingga anak yang demikian akan disukai oleh banyak orang dalam pergaulannya. Karakter semacam inilah yang penting semestinya dimiliki oleh setiap pribadi anak 
didik agar berhasil dalam membangun komunikasi dan pergaulan dengan orang lain sehingga mampu membawa dirinya kepada keberhasilan belajar disekolah.

Lebih lanjut penulis menyatakan bahwasannya karakter yang juga perlu dibangun pada anak didik disekolah adalah karakter patuh pada aturan sosial. Karakter patuh terhadap aturan sosial adalah merupakan sebuah sikap yang harus dikembangkan karena sikap tersebut akan dapat mengubah paradigma anak didik. Dimana anak didik akan menurut dan taat terhadap aturan-aturan berkenaan dengan tata tertib disekolah maupun dimasyarakat demi kepentingan bersama. Aturan-aturan sosial dan tata tertib dibuat untuk kebaikan bersama dan melindungi kepentingan umum. Anak didik yang bisa mengikuti aturan sosial dianggap oleh masyarakat sebagai orang yang baik. Sebaliknya, anak didik yang tidak bisa mematuhi aturan sosial atau tata tertib sekolah biasanya ada sanksi sosial yang diterimanya, setidaknya anak didik akan dijauhi dari pergaulan. Oleh sebab itu, atauran sosial ini hendaknya kita perhatikan di manapun kita berada.

\section{3) Karakter Terkait dengan Lingkungan (Palemahan)}

Untuk menerapkan pendidikan Karakter tentunya tidak bisa dilakukan hanya oleh satu pihak saja. Ketika guru membentuk Karakter pada diri anak, sedangkan di lingkungan masyarakat ia melihat banyak nilai-nilai yang dilanggar, maka hanya ada dua kemungkinan, ia tetap berpegang teguh pada nilai-nilai yang telah dipelajari di sekolah, atau ia meninggalkan nilai-nilai tersebut dan mengikuti pelanggaran nilainilai yang terjadi di masyarakat. Oleh karena itu, anak didik juga harus dibangun karakternya yang berkaitan dengan lingkungan. Selain dua karakter tersebut di atas yang perlu dikembangkan, juga tidak kalah pentingnya karakter yang terkait dengan lingkungan yang juga harus dikembangkan dalam diri peserta didik. Karakter peduli terhadap lingkungan atau peduli sosial adalah sebuah sikap dan tindakan yang selalu berupaya untuk bisa memberikan bantuan kepada orang lain dan lingkungannya.

Menurut penulis karakter peduli lingkungan yang bisa ditunjukkan adalah dengan selalu bersikap dan bertindak melakukan pencegahan terhadap adanya kerusakan lingkungan alam yang ada disekitarnya. Hal ini bisa dilakukan dengan tidak membuang sampah sembarangan, menebang pohon sembarangan, membersihkan selokan, dan lainlain.

Oleh karena itu, lembaga pendidikan atau sekolah berkewajiban untuk membangun karakter peserta didik agar mempunyai karakter yang bisa membangun nilai-nilai kebangsaan dan berjiwa nasionalis. Sebab, karakter peserta didik yang mencintai nilainilai kebangsaan dalah peserta didik yang mampu berpikir, bertindak, dan memiliki wawasan yang dapat menempatkan kepentingan umum di atas kepentingan dirinya sendiri. Nilai-nilai kebangsaan tersebut sangat penting untuk dapat dibangun pada diri peserta didik, mengingat betapa tidak jarang saat ini kita sebagai seorang pendidik menyaksikan di berbagai media para politisi dan pejabat di negeri ini seakan-akan hanya mementingkan dirinya sendiri dan kelompoknya bahkan sebagai alat partainya. Semestinya mereka mendahulukan kepentingan bangsa dan negara ketimbang kepentingan pribadi dan kelompoknya.

Oleh sebab itu dijaman globalisasi seperti sekarang inilah pendidikan karakter sangat perlu kembali dibangun pada peserta didik agar memiliki pondasi mental yang kuat sehingga dalam diri peserta didik tumbuh dan berkembang jiwa nasionalismenya. Karena orang yang berjiwa nasionalisme akan dapat berpikir, bersikap, dan berbuat yang mampu menunjukkan kesetiaan, kepedulian, dan penghargaan yang tinggi terhadap lingkungan fisik, bahasa, sosial budaya, politik dan ekonomi bangsanya. Oleh 
karena itu, guru dan orang tua serta lembaga pendidikan mempunyai tugas dan tanggung jawab untuk membangun karakter peserta didik tersebut dengan baik.

\section{KESIMPULAN}

Untuk mencapai keberhasilan pendidikan maka diperlukan pembentukan karakter terlebih dahulu. Pembentukan karakter tersebut tidak bisa dilakukan hanya oleh seorang guru saja, namun harus bersinergi dengan orang tua peserta didik itu sendiri. Selain itu kepberhasilan peserta didik juga dipengaruhi oleh seorang guru yang bisa dijadikan sebagai tauladan disekolah, pendidikan karakter akan mudah untuk dibangun dalam sebuah lembaga pendidikan atau sekolah apabila adanya kerjasama antara guru dan para orang tua peserta didik.

Untuk mencapai keberhasilan pendidikan tersebut maka diperlukan adanya kemitraan sekolah dengan keluarga. Karena dengan adanya kemitraan antara sekolah dengan keluarga maka keberhasilan pendidikan akan dapat tercapai, sebab lingkungan keluarga merupakan lingkungan pendidikan yang pertama, karena dalam keluarga inilah anak pertama-tama mendapatkan didikan dan bimbingan. Juga dikatakan lingkungan yang utama, karena sebagian besar dari kehidupan anak adalah didalam keluarga, sehingga pendidikan yang paling banyak diterima oleh anak adalah dalam keluarga.

Pengaruh pendidikan karakter sangat menentukan keberhasilan peserta didik disekolah. Uutuk mencapai keberhasilan pendidikan anak-anak disekolah maka perlu ditanamkan karakter anak-anak seperti: rasa percaya diri; kemampuan bergaul; dan kemampuan berkomunikasisehingga nantinya anak-anak kita akan mampu membangun kepribadiannya sendiri sehingga akan tumbuh akhlak mulia.

Lembaga pendidikan memiliki tugas mempersiapkan terbentuknya individuindividu yang cerdas dan berakhlak mulia. Terbentuknya kedua kriteria ini memungkinkan terwujudnya kehidupan sosial yang ideal bagi anak-anak, dan akan dapat mewarnai semangat untuk mengembangkan potensi diri dan memanfaatkannya untuk mencapai kebahagiaan lahir dan batin serta keselamatan dunia akhirat. Untuk membentuk karakter tersebut maka konsep ajaran Tri Hita Karana sangat tepat untuk dikembangkan pada diri anak-anak sejak dini disekolah yang meliputi: karakter terkait dengan tuhan yang maha esa; karakter terkait dengan sesama manusia; dan karakter terkait dengan lingkungan.

\section{DAFTAR PUSTAKA}

Azzet, Akhmad Muhaimin. 2011. Urgensi Pendidikan Karakter di Indonesia. Jogjakarta: AR-RUZZ MEDIA.

Goleman, Daniel. 1995. Emotional Intelligence. Alih Bahasa T. Hermaya. Kecerdasan Emosional. Jakarta: Gramedia Pustaka Utama.

1998. Emotional Intelligence. Alih Bahasa T. Hermaya. Kecerdasan Emosional. Jakarta: Gramedia Pustaka Utama.

Hasbullah. 2008. Dasar-Dasar Ilmu Pendidikan Edisi Revisi. Jakarta: PT Raja Grafindo Persada.

Hasan, M. Iqbal. 2002. Materi Metodologi Penelitian dan Aplikasinya. Jakarta: Ghalia Indonesia.

Indrakusuma, Amier Daien. 1973. Pengantar Ilmu Pendidikan. Surabaya: Usaha Nasional. 
Moleong. 2010. Metodologi Penelitian Kualitatif. Bandung. Pt Remaja Mulyana, Dedi. 2001. Metodologi Penelitian Kualitatif, Paradigma Baru Ilmu Komunikasi dan Ilmu sosial lainnya. Bandung: Remaja Rosdakarya.

Schmuck, Richard A. Dan Patricia A. Schmuck. 1983. Group Process in the Classroom. Iowa: Wm.C. Brown Company Publisher.

Sokardjo, M. dan Komarudin, Ukim. 2009. Landasan Pendidikan Konsep dan

Zuchdi, Darmiyati. 2010. Humanisasi Pendidikan Menemukan Pendidikan Yang Manusiawi. Jakarta: PT Bumi Aksara. 